\title{
NOTES ON THE PALAEOGEOGRAPHICAL SETTING OF THE EOCAMBRIAN TILLITE-BEARING SEQUENCE OF SOUTHERN PEARY LAND, NORTH GREENLAND
}

\section{Lars B. Clemmensen}

The Morænesø Formation is a tillite-bearing unit (Jepsen, 1971a) occurring in southern Peary Land (fig. 3). It follows stratigraphically the Precambrian Inuiteq Sø Formation (Jepsen, 1971a) and is in turn overlain by the Eocambrian or early Cambrian Portfjeld Formation (Jepsen, 1971a).

On J. C. Christensen Land and Valdemar Glückstadt Land (fig. 3) the Campanuladal Formation $(\simeq$ Campanuladal Sandstones and Limestones of Adams \& Cowie, 1953) overlies Precambrian basalts (fig. 4) and is capped by either the Fyns Sø Formation $(\sim$ Fyn Sø Dolomite of Adams \& Cowie, 1953) or the Portfjeld Formation.

The primary aim of this initial survey is to outline the sedimentary facies of the til-

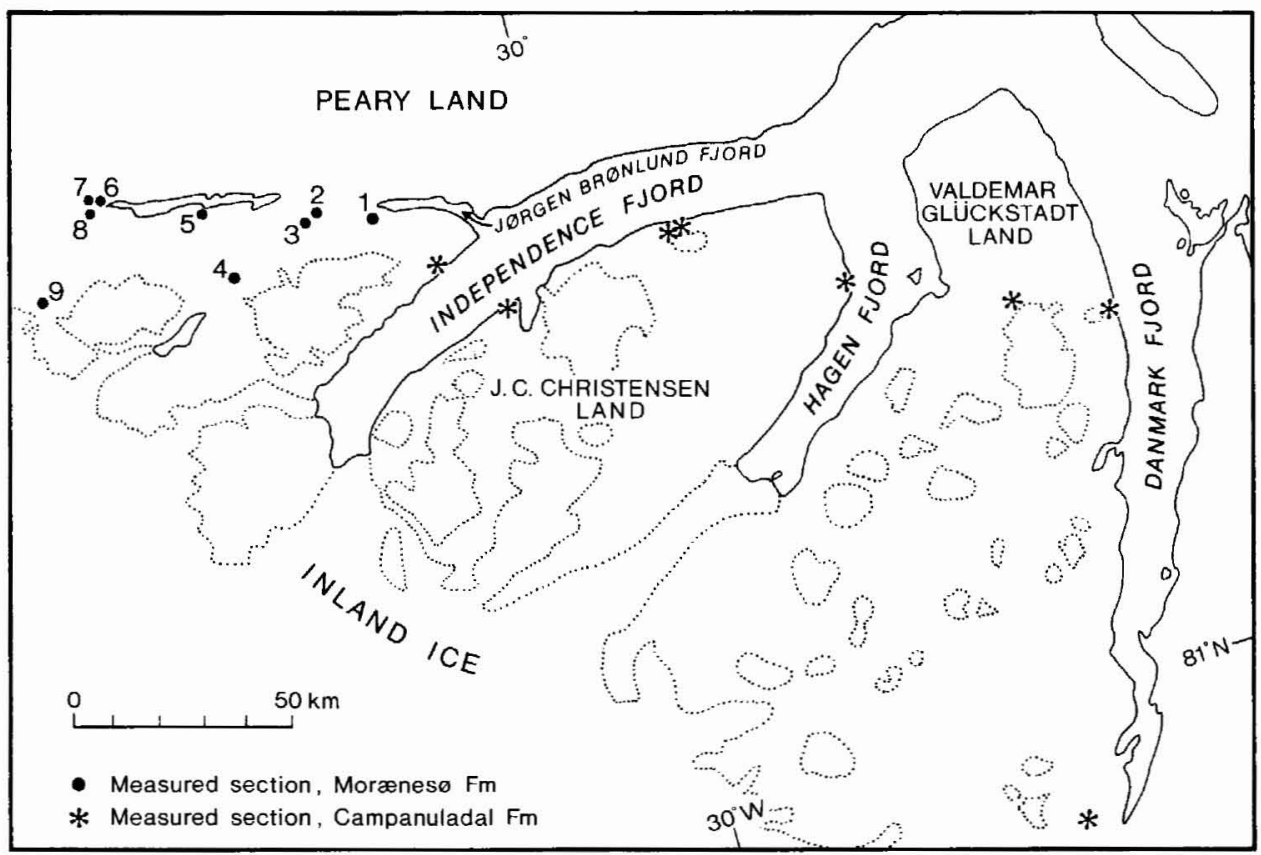

Fig. 3. Location map with geographical position of investigated sedimentary sequences. 
lite-bearing Morænesø Formation. For an understanding of the environmental setting of this sequence it is necessary briefly to consider the contemporaneous Campanuladal Formation, and the overlying Fyns Sø Formation.

\section{The Morænesø Formation}

Red diamictites, conglomerates and pebbly sandstones characterizing the formation were interpreted, in the main, as tillites by Troelsen (1950) and Jepsen (1971a). The present study indicates the majority of rocks to be of fluvial or lacustrine origin. A glacial origin for some diamictites is suggested by massive appearance, great thickness of individual beds, clast shape, striations and dropstones in associated facies. The tillites and water-laid sediments are associated with aeolian sandstones and overlain by shallow marine sediments (fig. 5). Vertical facies distribution varies considerably, especially in the lower continental part of the sequence (fig. 5). Two marker horizons (facies 9 and 10, fig. 5) occur in the upper part of the formation.

\section{Massive red diamictite}

This facies consists of up to $45 \mathrm{~m}$ thick diamictite with scattered pebbles and boulders in a sandy matrix. The clasts normally constitute 10-20 per cent of the sediment. Some boulders are more than $1 \mathrm{~m}$ in diameter, though the majority of the larger clasts are $20-60 \mathrm{~cm}$ in

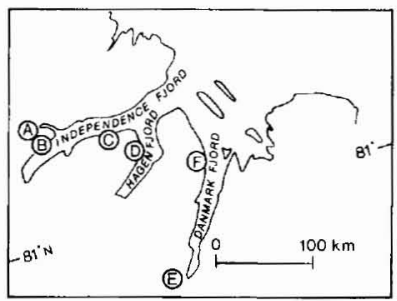

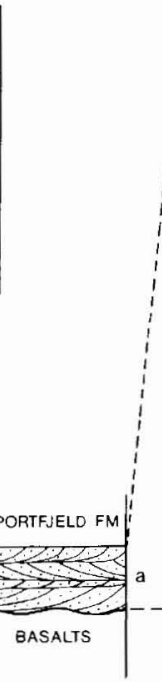

(C)

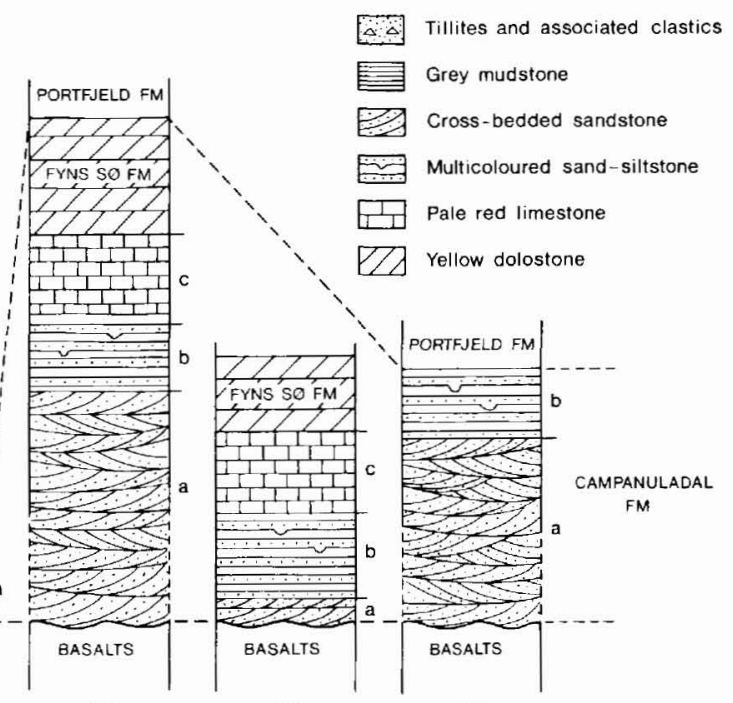

(E)

(F)

Fig. 4. Stratigraphical sections of the Campanuladal Formation in southern Peary Land, J. C. Christensen Land and Valdemar Glückstadt Land. The correlation between the Morænesø Formation and the Campanuladal Formation is based on stratigraphical position. Facies associations in the latter are indicated by $a, b, c$ and $d$. 
diameter. Abraded angular clasts, $c$. 5 per cent of which display glacial striae, dominate. At most localities locally derived quartzites, sandstones and dolerites dominate the block assemblage, but a few gneiss and iron rich erratics occur. The clasts may be randomly orientated or with their longest axis dipping towards the SE, indicating glacial movement from that direction. Glacial striae on clasts agree with such an ice transport pattern. Fluvial sandstones and rare siltstones between $10 \mathrm{~cm}$ and a few metres thick are interbedded in the diamictite. Many of these sandstones show well-developed, intricate deformation structures. In two levels large periglacial sand polygons with a diameter up to $c .10-20 \mathrm{~m}$ are developed. Apart from well-developed horizontal and minor vertical jointing the tillite is massive.

The facies is interpreted as a tillite and the large thickness and massive nature suggest a subglacial origin. However, the fluvial sandstones, and especially the sand polygons indicate at least some periods of glacial retreat and subaerial exposure.

\section{Laminated red diamictite}

This facies is less common than the massive tillite and appears in beds no more than a few metres thick. The lamination is due to the occurrence of thin light grey sandy layers or lenses between the conglomeratic red sandstone, the latter being identical to the former facies.

While the lamination at some places be explained as shear banding in a lodgement till, a flow till origin is suggested elsewhere by the association of this facies with lacustrine fine sandstones and siltstones.

\section{Rhythmically bedded fine sandstones and siltstones with 'dropstones'}

This facies only occurs at two horizons at one locality, in beds up to $c .2 \mathrm{~m}$ thick. It is typically composed of sand- or granule-rich layers overlain by fine sand or silty layers. Each sedimentary couplet is less than one centimetre to a few centimetres thick and the horizontal lamination is frequently disrupted by $2-10 \mathrm{~cm}$ large angular clasts. The orientation and size of many af these clasts implies that they are 'dropstones'.

The rhythmic bedding, the occurrence of numerous 'dropstones' and a gradational contact to lower and upper massive tillite strongly suggest a glaciolacustrine origin of the facies.

\section{Cross-bedded yellow sandstone}

The facies, which is composed of well-sorted medium sandstone, occurs up to $c .3 \mathrm{~m}$ thick and is associated with fluvial pebbly sandstones and massive tillites. The cross-bedding constitutes large-scale planar or wedge-shaped sets indicative of transport from the southeast.

The well-sorted appearance of the sandstones and the nature of the cross-bedding suggest an aeolian origin. 


\section{Red horizontally laminated sandstone}

This facies is composed of horizontally laminated well-sorted medium sandstone, with occasional large-scale cross-bedding. Large angular sandstone clasts mainly of intraformational origin are scattered throughout.

The facies is interpreted as an aeolian deposit, reworked to varying degrees by fluvial currents. The angular nature of the sandstone blocks could indicate that they were transported in a frozen condition.

\section{Stratified conglomerate and pebbly sandstone}

The facies comprises a large number of subfacies, with matrix-supported faintly horizontally stratified conglomerates the dominant rock type. The horizontal stratification is due to a subparallel orientation of most clasts and the occurrence of laminated granule or coarse sandstone layers. Most of the clasts are subrounded and the largest are between c. 25 and 50 $\mathrm{cm}$. Associated facies include trough cross-bedded pebbly sandstones (transport towards the northwest), horizontally stratified clast-supported conglomerates and breccias with large angular clasts up to 2-3 $\mathrm{m}$. Small periglacial sand polygons occur in association with the finer subfacies.

It is suggested that most of the facies were deposited in glaciofluviatile environments characterized by ephemeral stream-floods and debris flows. Some conglomerates, however, may have been deposited by sedimentary gravity flows in a lacustrine environment.

\section{Graded sandstones with thin mudstones}

This facies was seen at one locality with a thickness of $c .7 \mathrm{~m}$. The sandstones, between 2-5 $\mathrm{cm}$ thick show distinct normal grading. Mudstone clasts along the lower contact and small-scale cross-bedding at the top are common. Intervening mudstones are only a few millimetres to $c .1 \mathrm{~cm}$ thick.

This facies is interpreted as glaciolacustrine with the sandstones presumably being deposited from 'turbidite' underflows.

\section{Red horizontally laminated siltstone}

This facies only occurs in the upper part of the formation and is predominantly horizontally laminated. Some graded beds and wave-rippled horizons are present.

The facies is interpreted as lagoonal because of its transitional boundary to overlying shallow marine sandstones.

\section{Yellow stromatolitic dolomite}

This facies is composed of a $2.5-4 \mathrm{~m}$ thick sheet of dolomite characterized by the development of various types of stromatolites. The most impressive described by Troelsen (1950), constitute 2.5-3 m thick domes with centimetre-thick lamination. Others are small 
centimetre-size domes with thin millimetre lamination, and they occur within massive and vuggy dolomite. Oncolitic dolomite is also present.

The various subfacies presumably originated in intertidal marine environments.

\section{Grey quartz sandstone}

This sediment constitutes the uppermost part of the formation and is composed of medium-coarse sandstone with pebble-rich layers at the top. Sedimentary structures include cross-bedding (orientated NE-SW), horizontal lamination and wave ripples.

This facies is interpreted as beach and shallow marine shoreline deposits.

\section{The Campanuladal Formation}

In most of northern J. C. Christensen Land and northern and eastern Valdemar Glückstadt Land this formation is composed of three well-defined facies associations (fig. 4 and map 1): a basal sandstone association, a middle multicoloured sandstone-siltstone association and an overlying red limestone association. A fourth facies association (fig. 4) occurs locally along the Independence Fjord (fig. 3) and is characterized by red sandstones overlain by grey mudstones with graded sandstone interbeds.

\section{a. Basal sandstone facies association}

This facies association varies in thickness from $55 \mathrm{~m}$ to $c .500 \mathrm{~m}$. It overlies Precambrian basalts (Jepsen \& Kalsbeek, this report) apparently unconformably, though no basal conglomerate has been seen. The lower part of the association consists of red medium sandstones, locally with small scattered pebbles. There is a gradational transition to the overlying yellowish medium sandstones. Trough cross-bedding with a bimodal NE-SW orientation is the characteristic sedimentary structure of the sandstones. Mud-cracks and mud-pebbles are common.

The sandstones are interpreted as intertidal to shallow subtidal marine sediments.

\section{b. Middle multicoloured facies association}

This facies association is composed of alternating units of red and green fine sandstones and siltstones. The thickness of the unit varies from $90 \mathrm{~m}$ to $170 \mathrm{~m}$. In the upper part a $0.5-3$ $\mathrm{m}$ thick stromatolitic horizon forms a good marker. Both the red and green sediments display coarse rhythmic bedding of alternating centimetre-thick sandstones and siltstones. The red and green sediments are predominantly horizontally laminated, but mud-cracks are more numerous in the former. Small channels, orientated NE-SW, between 5 and $30 \mathrm{~cm}$ wide occur at the base of many of the green sandstones.

Whereas the red sediments were apparently deposited in shallow lagoonal environments, the green sediments were deposited in somewhat deeper subtidal ?lagoonal water. The rhythmic bedding and the small channels indicate highly fluctuating depositional conditions. 


\section{c. Upper red limestone facies association}

This facies association is cliff-forming and has a maximum thickness of $175 \mathrm{~m}$. The basal part is composed of $20-40 \mathrm{~m}$ of dark red limestone with numerous load structures. The upper part consists of pale red limestone with intraformational breccias and locally up to 20 $\mathrm{m}$ of stromatolitic limestone. The upper boundary is defined by the gradual change to the yellowish dolomites of the Fyns Sø Formation. In contrast to the lower two associations this limestone association only occurs along the southwestern shore of Danmark Fjord and the western shore of Hagen Fjord (fig. 5).

The sediments are tentatively ascribed to various shallow marine environments.

\section{d. Grey mudstone facies association}

This facies association is named after its most characteristic facies, grey, horizontally laminated mudstones. The mudstones, which are up to $300 \mathrm{~m}$ thick, are interbedded with graded sandstones with sole marks, and are underlain by 8 to $300 \mathrm{~m}$ of red sandstones. This association which overlies either the Precambrian Inuiteq Sø Formation or the Precambrian basalts, is in turn overlain by the Portfjeld Formation. On the north side of Independence Fjord Jepsen (1971b) included these sediments in the Morænesø Formation. However, as the association contains no tillites or conglomerates, it is here regarded as part of the Campanuladal Formation.

The mudstones are interpreted as offshore? marine deposits.

\section{The Fyns Sø Formation}

This formation, which occurs at southern Danmark Fjord, on eastern Valdemar Glückstadt Land and on northeastern J. C. Christensen Land, is composed of cliff-forming yellow dolostones. The thickness varies greatly and reaches a maximum of $c .300 \mathrm{~m}$ at southern Danmark Fjord and at Hagen Fjord. On J. C. Christensen Land the formation thins drastically towards the west where it is replaced by the Portfjeld Formation.

The Fyns Sø Formation consists of massive vuggy yellow-weathering dolostones; horizons with stromatolites are common especially near the top. The stromatolites in the uppermost beds typically develop long slender columns with common branching. These were originally described as cone-in-cone structures by Adams \& Cowie (1953).

The formation overlies variegated limestones of the Campanuladal Formation with a transitional boundary, and the Fyns Sø Formation is capped either by grey chert-bearing dolostones of the Portfjeld Formation or by dark grey siltstone and light grey sandstones of the Kap Holbæk Formation (= Kap Holbæk Sandstone of Adams \& Cowie, 1953). The boundary between the Fyn Sø and the Portfjeld Formation is difficult to define since clastic intervals up to $40 \mathrm{~m}$ thick intervene between the two dolostone units at some localities.

\section{Palaeogeography}

After the deposition of the Precambrian Inuiteq Sø Formation in southern Peary Land and the intrusion of the dolerites (Jepsen, 1971a), there was a considerable pause in 
sedimentation. The Precambrian surface was eroded by glacial, fluvial and probably aeolian agents. Small hills were formed where the hard dolerites were more resistent to erosion. The Morænesø Formation was mainly deposited in the topographically low levels of this Precambrian land surface, and the formation thins or is absent over topographically higher features. The initial deposits in most places are of fluvial or even aeolian origin, only rarely does the massive tillite rest directly on the Inuiteq Sø Formation (fig. 5).

Tillites have only been observed within a $70 \mathrm{~km}$ long E-W belt with a maximum width of c. $5 \mathrm{~km}$. Combined evidence from till-fabric and cross-bedding in fluvial and aeolian sandstones indicate that the glacier(s) came from the south or the southeast. However, further in this direction on J. C. Christensen Land and Valdemar Glückstadt Land, there are no glacial conglomerates or major unconformities within the Campanuladal Formation. Thus, it appears that the Eocambrian glacier(s) in North Greenland were of restricted size.

Following the deposition of the glacial deposits there was a gradual transgression in southern Peary Land as is evident from the deposition of stromatolitic dolostones and quartz sandstones (fig. 5). The sea apparently lay to the southeast covering J. C. Christensen Land and Valdemar Glückstadt Land during the main part of the Eocambrian.
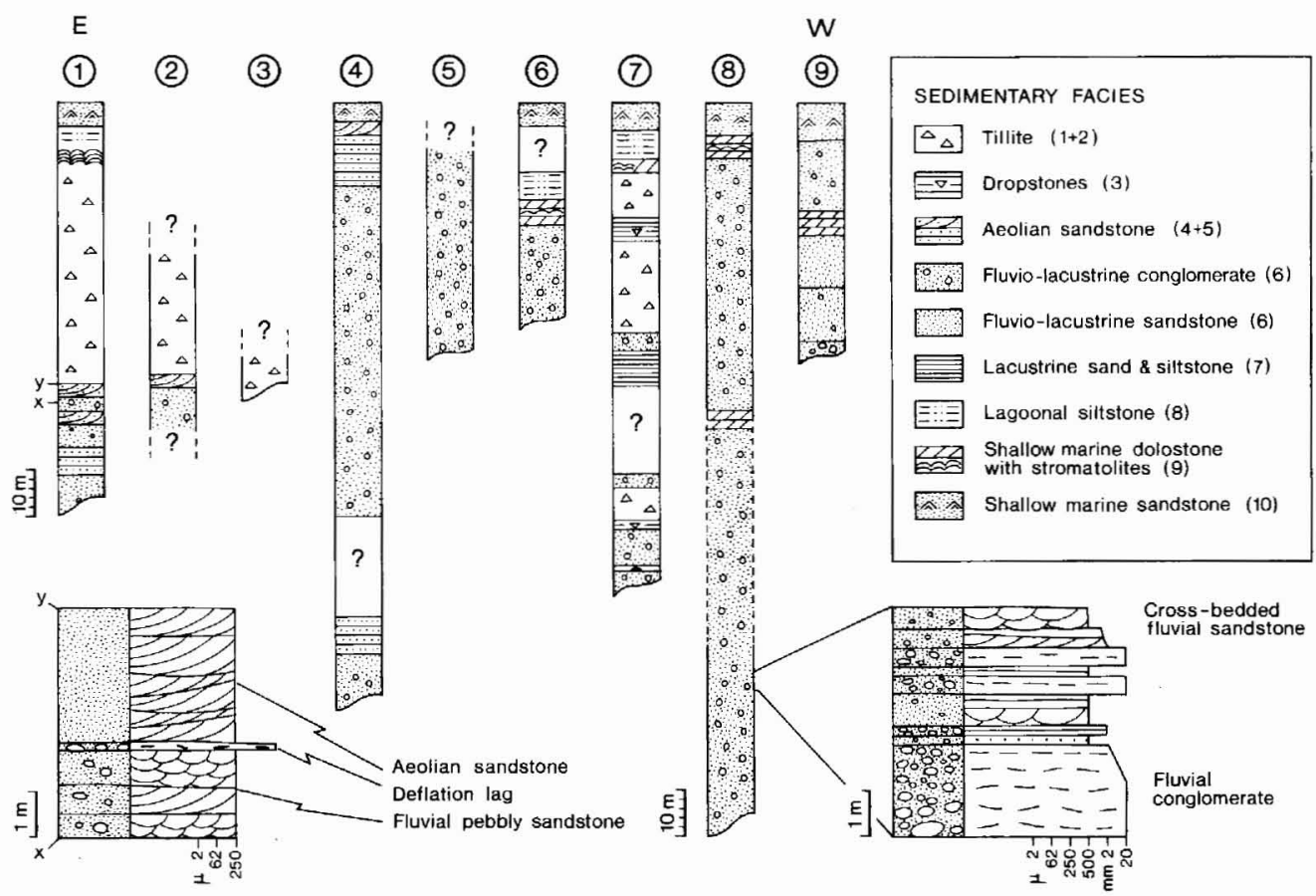

Fig. 5. Simplified sedimentary logs of the Morænesø Formation, southern Peary Land. The upper shallow marine quartz sandstone (facies 10) has been used as a marker horizon. Section 6 is based on unpublished observations by J. S. Peel (GGU). Facies numbers refer to descriptions in the text. See fig. 3 for location of the logs. 


\section{Conclusions}

1. The massive tillites of the Morænesø Formation are interpreted as lodgement tillites and were deposited in association with flow tillites and lacustrine, fluvial and aeolian sediments. Dropstones occur locally in the lacustrine rocks.

2. The tillites and associated continental deposits were ultimately transgressed by the sea, and shallow marine dolostones and quartz sandstones were deposited.

3. The most common facies in the Morænesø Formation is water-laid matrix-supported conglomerate. The environmental significance of this facies can only be evaluated after detailed studies of Quaternary glaciofluvial conglomerates.

4. Glacial conglomerates are absent in the mainly shallow marine Campanuladal Formation, which was deposited to the south of the Morænesø Formation.

\section{References}

Adams, P. J. \& Cowie, J. W. 1953: A geological reconnaissance of the region around the inner part of Danmarks Fjord, Northeast Greenland. Meddr Grønland 111, 7, 24 pp.

Jepsen, H. F. 1971a: The Precambrian, Eocambrian and early Palaeozoic stratigraphy of the Jørgen Brønlund Fjord area, Peary Land, North Greenland. Bull. Grønlands geol. Unders. 96 (also Meddr Grønland 192, 2) $42 \mathrm{pp}$.

Jepsen, H. F. 1971b: Notes on the Precambrian to Lower Cambrian stratigraphy of the south-eastern part of Heilprin Land, Independence Fjord, North Greenland. Rapp. Grønlands geol. Unders. 35, 9-10.

Troelsen, J. (C.) 1950: Geology. In Winther, P. C. et al. A preliminary account of the Danish Pearyland Expedition, 1948-49. Arctic 3, 6-8. 